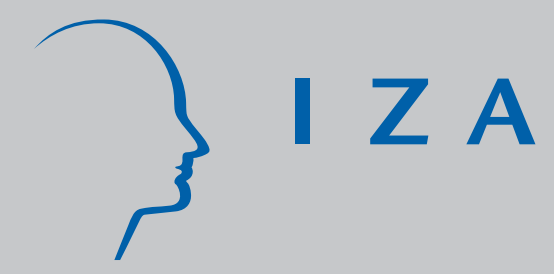

IZA DP No. 3384

The Rise and Fall of the American J ewish PhD

Barry R. Chiswick

March 2008 


\title{
The Rise and Fall of the American Jewish PhD
}

\author{
Barry R. Chiswick \\ University of Illinois at Chicago \\ and IZA
}

\section{Discussion Paper No. 3384 \\ March 2008}

\author{
IZA \\ P.O. Box 7240 \\ 53072 Bonn \\ Germany \\ Phone: +49-228-3894-0 \\ Fax: +49-228-3894-180 \\ E-mail: iza@iza.org
}

\begin{abstract}
Any opinions expressed here are those of the author(s) and not those of IZA. Research published in this series may include views on policy, but the institute itself takes no institutional policy positions.

The Institute for the Study of Labor (IZA) in Bonn is a local and virtual international research center and a place of communication between science, politics and business. IZA is an independent nonprofit organization supported by Deutsche Post World Net. The center is associated with the University of Bonn and offers a stimulating research environment through its international network, workshops and conferences, data service, project support, research visits and doctoral program. IZA engages in (i) original and internationally competitive research in all fields of labor economics, (ii) development of policy concepts, and (iii) dissemination of research results and concepts to the interested public.
\end{abstract}

IZA Discussion Papers often represent preliminary work and are circulated to encourage discussion. Citation of such a paper should account for its provisional character. A revised version may be available directly from the author. 


\section{ABSTRACT}

\section{The Rise and Fall of the American Jewish PhD*}

This paper is concerned with trends over the post-WWII period in the employment of American Jews as College and University teachers and in their receipt of the PhD. The empirical analysis is for PhD production from 1950 to 2004 and Jews are identified by the Distinctive Jewish Name (DJN) technique. Descriptive statistics and multiple regression analyses are reported. Central roles are played in the regression analysis by variables for military conscription, the Korean and Vietnam Wars, and US government funding for research and development. Among the DJNs, the simple data show that male PhD graduates increased in number in the post-war period up to early 1970s, and declined thereafter. Among DJN women, however, annual PhD production increased throughout the period. The ratio of DJN to all PhDs declined throughout the period for both men and women. Other variables the same, male DJN PhD production increased to about 1967 and then declined, while for DJN females it increased throughout the period. The ratio of DJN to all PhDs started to decline among men in the 1950s and continued thereafter, while among women the DJN share increased until about 1979, and then declined. These data are consisted with the hypothesis that discrimination against Jews in salaried professional occupations declined in the post-WWII period earlier in College and University teaching than in other sectors of the economy that do not require a PhD degree for employment.

JEL Classification: $\quad \mathrm{I} 21, \mathrm{~J} 71, \mathrm{~J} 44$

Keywords: American Jews, education, discrimination, gender

Corresponding author:

Barry R. Chiswick

Department of Economics

University of Illinois at Chicago

601 South Morgan Street

Chicago, IL 60607-7121

USA

E-mail: brchis@uic.edu

\footnotetext{
* Marshall Sklare Memorial Lecture, Association for the Social Scientific Study of Jewry, Toronto, December 2007. I appreciate the research assistance of Jidong Huang and Benjamin Yarnoff, and the comments received on an earlier draft from Carmel U. Chiswick, Rela Geffen, Paul Pieper, Jonathan Sarna, and Ira Sheskin, as well as participants in the Marshall Sklare Memorial Lecture session.
} 
Revised 3/3/2008

“The Rise and Fall of the American Jewish PhD”

Barry R. Chiswick

\section{$\underline{\text { Introduction }}$}

It is an honor for me to be the recipient of the Marshall Sklare Award. Although it is my misfortune that I never met him, I am aware of Prof. Sklare’s role as the “dean” of American Jewish sociology. The annual award named in his memory has been bestowed annually since 1992 on a long list of distinguished sociologists, demographers, anthropologists and historians who have advanced the field. I am especially appreciative of this award as I am the first "card carrying” economist to be so honored. I view this not as an award just for me, but as an acknowledgement of the return by economists to the social science study of Jewry. One cannot ignore the important research conducted decades ago by both Simon Kuznets and Arcadius Kahan on the economic status of Jews in the Russian Empire and the United States. But then, for several decades the Jewish studies and the economics literatures were devoid of research on the economics of Jews or Jewry.

This paper is concerned with a topic of particular interest to the membership of the Association for the Social Scientific Study of Jewry, as well as the Association for Jewish Studies, the increase and then the decline of Jews teaching in the colleges and universities in the United States. Section I explains the methodology of economics, and the origin of any interest in this topic. The source of the data for PhDs awarded, and the algorithm for identifying Jews in these data (Distinctive Jewish Names, DJN) are discussed in Section II. Data regarding the number of PhDs received over time, by major discipline, by Jews and by Jews relative to all 
PhDs, are reported in several figures in Section III. The model to be used for the multivariate analysis of the determinants of $\mathrm{PhD}$ production is developed in Section IV. The multiple regression analyses of the number of PhDs received by those identified as Jews and the ratio of these to all $\mathrm{PhDs}$ are reported in Section V. This is followed (Section VI) by a summary and conclusion.

\section{Economics and Jewish Studies}

Economics is the study of the allocation of scarce resources among competing objectives. One scarce resource is time, and economists have become interested in the allocation by individuals of their time. An important use of time is investment in skills, including general human capital and religious human capital. Interesting work on the determinants and consequences of investment in religious human capital, including Jewish human capital, in recent years has been done by economists Laurence Iannaccone and Carmel Chiswick.

My research in Jewish studies has focused on earnings and the determinants and consequences of investments in skills, including formal schooling, language training, occupational attainment and labor market (on-the-job) training of American Jewry and Jewish immigrants in Israel. Jewish investments in one form of human capital, the PhD degree, is the subject of this lecture.

Economics is essentially an empirical area of inquiry that relies on the scientific method (Friedman 1957). Typically there is an observation, often informal, about the world in which we live, which stimulates the development of a model or hypotheses to explain the observation, to be followed by empirical analysis using independent but real world data to test the validity and robustness of the model or hypotheses. Economic models typically began with the assumption that, subject to constraints, businesses seek to maximize profits and individuals seek to maximize 
their economic well-being, or utility where utility, is not directly measurable, but is an important concept.

My interest in the title of this paper, the "Rise and Fall of the American Jewish PhD" started with a set of inter-related observations. When I was a doctoral student of Economics at Columbia University, in the dim ages of the 1960s, a substantial proportion of my fellow graduate students were Jewish, as was the case at that time of young PhD economists in general, even outside New York City. ${ }^{1}$ Yet, it appeared to me that in recent decades this has not been the case. Moreover, I noticed that the Hillel Faculty Group in Chicago, that attracted Jewish faculty from many of the colleges and universities in the Chicago Metropolitan Area, has aged over the past nearly 3 decades of its existence. The same faces, a bit more wrinkled and with greyer hair, would attend year after year, with very little new blood. Finally, although clearly a select sample of academics, the membership of the Association for the Social Scientific Study of Jewry faces the same problem—-the scarcity of young scholars working in this area.

When I embarked on my project on the occupational attainment of American Jews since 1890, I included a separate tabulation of those in College and University Teaching in the professional occupation category for the post-WWII period (Chiswick 1999, 2007). In spite of small sample sizes and problems of comparability over time, the data showed a rise in the postWWII period in the proportion of Jewish men who were in College and University Teaching up to the approximately 5 percent in the 1972-1987 pooled data from the NORC General Social Survey, in contrast to the one percent among non-Jewish white men. The proportion among Jews was about 3 1/2 percent in the 1990 National Jewish Population Survey, and less than 2 percent in the 2000 National Jewish Population Survey, although that was twice the rate among white men

$1 \quad$ Marshall Sklare also received his PhD from Columbia University, but in 1953. 
in the 2000 Census of the United States. A more detailed examination of the NJPS data on men revealed that the College and University Teachers age 25 to 64 in the 1990 NJPS tended to be older and many would have been older than 65 years in 2000. Meanwhile, what was not seen in the 2000 NJPS data was young male Jewish academics.

A similar pattern is found among Jewish women in the NJPS who reported an occupation. While the proportion of Jewish women in College and University Teaching was over 2 percent in the 1990 NJPS, four times that of white women, by the 2000 NJPS it was less than one percent, about the same as white women (Chiswick 2007).

Note that these declines in the proportion of Jews in College and University Teaching came at a time when the proportion of Jews in other professional occupations was on the increase. From 1990 to 2000 the proportion of Jewish men in professional occupations other than College and University Teaching increased from 39 percent to 51 percent, and for women from 40 percent to 50 percent. Thus, Jews aspiring to professional occupations have in recent decades, more so than before, entered fields other than College and University Teaching. This appears to be a real finding and not an artifact of sampling variability or other sampling problems.

The question: "What caused the rise and fall among Jewish academics?” led to the question: "What has happened in the post- WWII period to the receipt of PhDs by American Jews?” While it is true that not all College and University Teachers have PhDs, it has increasingly become a "union card" or job requirement, even in two-year institutions and small liberal arts colleges where academic-type research is neither required nor expected of the faculty. It is also true that many $\mathrm{PhD}$ recipients do not enter the US academic job market, but rather take jobs in government, the private (non-academic) sector or abroad. Yet, given the large proportion 
of new PhDs who enter the academic job market, trends in $\mathrm{PhD}$ production can shed light on both the educational attainment and occupational patterns of American Jewish men and women.

Prior to World War II there was considerable discrimination against Jews in many sectors

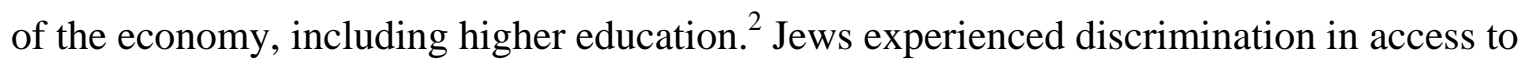
colleges and universities, as both students and faculty. ${ }^{3}$ There was, however, also discrimination in access to employment in other sectors, including high level positions in heavy manufacturing, insurance (other than as salesmen), banking, engineering, and law firms, among other sectors, with the exception of Jewish owned firms. ${ }^{4}$

Jews found niches in other sectors of the economy. These started as small enterprises that often required little start-up capital (e.g., retail trade, garment industry). Independent professional practice, such as law, medicine and accounting also attracted Jews. Other sectors that Jews entered were not held in high social repute, such as entertainment, including the theatre, vaudeville and movie industries.

2 The economic analysis of discrimination was developed in Becker (1957). This lecture was delivered on the $50^{\text {th }}$ anniversary of the publication of this classic study.

3 Within the Economics profession there are well known stories of discrimination in the 1940’s against hiring Paul Samuelson at Harvard (he went on to establish the Economics Department at MIT) and Milton Friedman at UCLA. Both later received the Noble Prize in Economics. Diner (2004, p.210) writes that: “Through the early 1930's no more than one hundred Jews held professional positions in American universities” and comments on substantial discrimination against Jews in college and university admission, prestigious law firms, banks, public utilities and many other sectors of the economy. Diner (2004, p.223-4) relates the difficulties of Lionel Trilling and Robert Merton (born Shkolnik) in academia. These barriers against Jewish men diminished in the early post war years and largely disappeared by the late $20^{\text {th }}$ century. Freidenreich (2007) writes of the even greater discrimination against Jewish women in academia than against Jewish men until the 1970s. For discussions of the decline in antisemitism in academia and in general in the post-war period, see also Lipset and Ladd (1971), Shapiro (1992, Chapter 2) and Chanes (1999).

$4 \quad$ For a discussion of apparent discrimination against Jewish Harvard MBAs in less competitive sectors compared to more competitive sectors of the economy, see Alchian and Kessel (1962). 
What Jews did was to seek out, and at times create, niches where they could exercise their entrepreneurial and creative talents, subject to a minimum of discrimination. It appears that in the post-WWII period this discrimination gradually decreased, but with the decline coming earlier, and perhaps most intensely, in higher education. ${ }^{5}$ If Jews interested in advanced education would seek out the niches where discrimination against them would be least intense, it is hypothesized that in the early post-war years they would tend to obtain PhDs and enter academic employment. ${ }^{6}$ Later, as employment opportunities in other high level occupations became available, the relative attractiveness of an academic career, and hence the demand for a $\mathrm{PhD}$ among Jews, would decline. This hypothesis suggests that the absolute number and the ratio of Jewish to all PhDs would decline over the course of the post-war years, other variables being the same.

\section{Identifying Jewish PhDs}

The $\mathrm{PhD}$ degree requires a doctoral dissertation, and these dissertations are deposited at University Microfilms, University of Michigan, Ann Arbor. The data recorded for each dissertation includes the author's name, dissertation title, field of study, degree granting institution, and year of completion. It is, therefore, possible to develop a list of the family names

$5 \quad$ In their analyses of the changes over time in "Jewish learning” (i.e., courses and research on Judaism and Jews) in the $19^{\text {th }}$ and $20^{\text {th }}$ centuries Ritterband and Wechsler (1994) discuss the effects of anti-semitism on the hiring of Jewish faculty.

$6 \quad$ A consequence of discrimination against Jewish faculty in many of the premier colleges and universities was that non-discriminating institutions could attract outstanding Jewish scholars. This accounts for the extraordinarily high quality of the faculty at City College of New York (and the other public institutions that were later combined as the City University of New York) in the 1930's and early post-WWII years. As discrimination against Jews (and African/Americans) declined in higher education, the competitive edge in recruiting and retaining outstanding Jewish and other minority faculty held by the original non-discriminating institutions declined. Freidenreich (2007) comments on the lesser degree of discrimination against Jewish women in the public colleges in New York City than elsewhere. 
or surnames of PhD recipients by discipline (Humanities, Social Science, Physical Science, Education, and total) from American universities in each year for the post-WWII period.

For this project Jews are identified by using the Distinctive Jewish Name (DJN) technique. Himmelfarb, et al. (1983) attribute the DJN technique to Samuel C. Kohs in 1942 and report the results of several studies that the list of 35 names (the names used here except for Schowartz) are held by 11 to 15 percent of Jews, with about 90 percent of individuals with these surnames being Jewish. If these proportions still hold, and if receipt of the $\mathrm{PhD}$ among Jews is independent of their surname, it suggests that the number of Jews receiving the $\mathrm{PhD}$ is 7 to 9 times greater than the number of DJN PhDs. Himmelfarb, et al., (1983) compare the socioeconomic and demographic characteristics of those on the DJN list with other Jews in the 1970 National Jewish Population Survey and conclude that the differences "were quite small” The DJNs differ by little from the other Jews in terms of ritual observance, and Jewish identification. Jews identified from organizational membership lists (e.g., synagogue memberships, Federation lists, etc.) differ by more from Jews not on these lists than DJNs differ from other Jews. A more recent study of the pros and cons of use of the 36 DJNs is found in Sheskin (1998).

In this study a person is identified as Jewish if the person's middle name or surname is on the DJN list. This, of course, results in two types of errors. One error is identifying as Jewish individuals with a surname or middle name on the list who are not Jewish, whether or not the person may have had a Jewish ancestor. An example would be the former Senator from Maine and Secretary of Defense, William Cohen. The second error is missing Jews who do not have a DJN. An example would be the 2007 Sklare Award recipient. Expanding the DJN list of names reduces the second error (missing Jews), but increases the first error (incorrectly identifying nonJews as Jewish). A relatively conservative DJN list of only 36 names is used in this study. 
Other problems with the DJN technique include name changes due to marriage. The check for DJNs among middle names is intended to identify Jewish women whose original surname is a DJN and is used as a middle name, but whose current surname is not on the list. In this instance marriage is a two-edged sword. A former colleague, Cohen changed her name to O’Neill upon marriage before completing her $\mathrm{PhD}$, and would not be identified as Jewish, while non-Jewish women adopting a DJN husband's surname would be so identified. Moreover, the DJN list focuses on Ashkenazic names, and hence Sephardic and Israeli names would not be identified, although most American Jews are of Ashkenazic origin.

Most important, the DJN technique is likely to provide an undercount of Jews receiving PhDs. ${ }^{7}$ Using the short list of 36 names it is likely that more Jews are missed than are individuals incorrectly identified as Jews. The purpose of this project, however, is not to count the number of Jewish PhDs, but rather to examine the trends over time. To the extent that the ratio of DJNs receiving the $\mathrm{PhD}$ to all Jews receiving the $\mathrm{PhD}$ is invariant over the post-WWII period, there is no bias in trends over time. While there has been a process of "Americanization” of Jewish names, if most of these name changes occurred at or shortly after immigration, given the immigration history of American Jews, the bias in the post-WWII list of names would be minimal.

The dissertation records do not contain information on the person's gender. The US Social Security Administration, however, has used birth records to compile frequency distributions for the names of boys and girls. Using data from 1960-1969, the list of the top 300

$7 \quad$ There are no estimates at the national level of the extent to which the DJN technique under estimates the number of Jews. Sheskin (1998) reports several estimates based on local studies which indicate that the size of the undercount is greater the greater the proportion of Jews in the population. In communities with very few Jews, but many people of German ancestry, it may even generate an overcount. 
boys names ( 88 percent of all boys born in the 1960s) and the top 300 girls names (78 percent of all girls born in the 1960s) is used to identify gender. While the frequency distribution for boys and girls names used by Jewish parents undoubtedly differs from that of non-Jewish parents, these lists are used for both Jews and non-Jews as I do not know of a comparable list just for Jews. Three categories are created: Boys, Girls, and Gender Not Identified (Name not on either list) ${ }^{8}$

The list of the Distinctive Jewish Names and the source for the top 300 names for boys and for girls are reported in the Statistical Appendix.

\section{II. $\quad$ Descriptive Statistics}

The graphs in Figures 1 to 6 record the number of DJNs receiving a $\mathrm{PhD}$ by year from 1950 to 2004 (Figure 1) and the ratio of the DJNs to total PhDs (Figure 2) in the United States in all fields. Figures 3 and 4 show these data separately for the physical sciences, the social sciences, education and the humanities. In Figures 5 and 6 the data on DJN PhDs and the ratios are shown separately by gender.

Across all fields, the number of DJN PhDs increased from an average of under 200 a year to a peak of about 525 per year in the 1970 s, with a rapid decline to under 400 a year in the first years of the $21^{\text {st }}$ century (Figure 1 ). As a proportion of all PhDs, however, the decade of the 1950s was the high point, with about 2 percent of all PhDs received by the DJNs, with the

$8 \quad$ For the PhD recipients, 1950 to 2004, the percent distribution of the top 300 male and the top 300 female given names:

$\underline{\text { Surname }}$

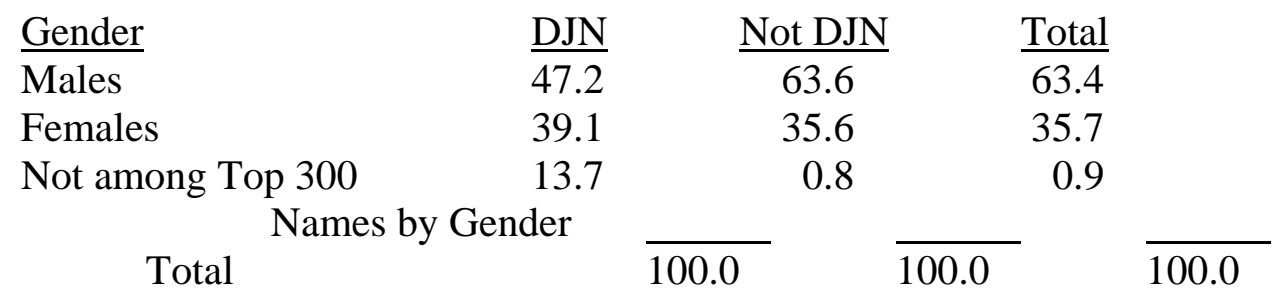


proportion declining in the 1960s, showing a bit of an increase in the late 1970s, and continuous declines thereafter to less than one percent since the late 1980s (Figure 2). Undoubtedly, some of the decline in the ratio in the past two decades has been due to the increase in the number of foreign students. Unfortunately, the University Microfilms data do not record the PhD recipient's country of birth, visa status or citizenship.

The patterns do differ somewhat across fields of study. Among the Physical Sciences there is a sharp increase in $\mathrm{DJN} \mathrm{PhD}$ degrees during the 1960s, from just over 100 per year in the early 1950s to a peak of 313 in 1972 (Figure 3). The level was maintained in the 1970s, with a decline in the 1980s and early 1990s to about 250 per year, and a sharper decline since the late 1990s (only 183 in 2004).

The ratio of DJN to all PhDs in the physical sciences shows a nearly continuous decline throughout the post-war period from nearly 2.5 percent in the1950s to about 0.8 percent since 2000 (Figure 4). The sharp increase in science PhD production among both Jews and non-Jews is likely to be reflecting the increase in public funding for science education following the USSR's launching of Sputnik in 1957. The increased funding provided more support for PhD students in the sciences and increased the demand for science faculty in colleges and universities.

A somewhat different pattern is found in the social sciences, where there was a sharp rise in DJN PhD awards from about 30 a year in the 1950s to about 115 per year in the 1970s, after which there was a decline until the nadir in the late 1980s (only 57 in 1987), with some modest recovery since then (Figure 3). The ratio of DJNs to all PhDs, however, was fairly steady through the 1950s to 1970 s (1.5 to 2.1 percent), with a decline in the 1980 s to about 1.0 percent in 1990, and it has held at that level since then (Figure 4). 
The number of DJN and non-Jewish PhDs in education is much smaller than in the physical or social sciences and as a result the annual volatility is greater. The data show a spike in DJN PhDs in the middle and late 1970s (Figure 3). The ratio also showed a peak in this period of about 1.4 percent, with the earlier and later periods of about or below one percent (Figure 4).

In the Humanities as well, there was a sharp increase in DJN PhDs received during the 1960s, a level number of over 80 per year in the middle 1970s (which was also the peak for the ratio) and a decline thereafter (Figures 3 and 4).

Although there are differences across the four major disciplines, a general pattern is an increase in the number of $\mathrm{DJN}$ receiving the $\mathrm{PhD}$ degree up to a plateau in the $1970 \mathrm{~s}$, and a decline thereafter. As to the ratio of DJN to all PhDs awarded, there appears to have been an initial increase followed by a trend toward a decline in later decades, both overall and within specific disciplines.

There are dramatic differences in the pattern of the receipt of PhDs by gender (Figure 5). The receipt of PhDs by male DJNs increased more rapidly than among female DJNs from 1950 to the early 1970s. ${ }^{9}$ The number of PhDs received by male DJNs then declined sharply, reaching a low point in the late 1980s, rebounded somewhat in the 1990s, and declined in the 2001-2004 period.

The number of women DJNs receiving a PhD increased until the early 1980s, declined in the mid-1980s, rebounded until a peak in the late 1990s, and has declined since then (Figure 5). Note, however, that since the late 1980 s more PhDs have been received by female than by male DJNs, with the gap being greatest in the middle 1990s.

\footnotetext{
$9 \quad$ For an historical account of discrimination against Jewish women in college and university teaching see Freidenreich (2007).
} 
The ratio of DJNs to all PhDs separately by gender, is shown in Figure 6. There is a sharp decline throughout the post-war period for men, although the ratio is erratic in the 1950s and early 1960s. The ratio is lower for women, less erratic, and declines more gradually over the post-war period.

\section{The Production of PhD Graduates: The Model}

The number of PhDs produced in a year will be a function of the demand for and the supply of $\mathrm{PhD}$ education. The higher the demand for and the greater the supply of $\mathrm{PhD}$ training opportunities, the greater will be the number of graduates. Because there is no direct measure of the "price" of $\mathrm{PhD}$ training, it is not possible to estimate the separate supply and demand equations. What can be estimated, however, is a "reduced form" equation where the number of $\mathrm{PhD}$ graduates in a year (or the ratio of Jewish to all graduates) is regressed on a series of explanatory variables that would be hypothesized to shift the supply and/or demand equations.

The demand for $\mathrm{PhD}$ education, of course, would be influenced by the earnings of $\mathrm{PhD}$ graduates. The salaries of Assistant Professors or academic salaries in general can serve as a proxy for general academic labor market conditions after graduation. I have not yet uncovered an appropriate time series for these data, so it is not included in the analysis.

A proxy variable for the probability of employment if one were not a doctoral student and for general labor market conditions can be entered into the analysis. The adult male unemployment rate can be used for this purpose. This variable is not included in the regressions reported below because preliminary estimations indicate that it was not statistically significant and its inclusion had no effect on the other explanatory variables. This is perhaps not surprising. Business cycles in the post-WWII period have been relatively mild and of short duration overall, and even more so for college graduates, the pool from which $\mathrm{PhD}$ candidates would be drawn. 
Data are not available on tuition and fee charges net of fellowships and scholarships. An important source of support for doctoral education, especially in the physical and to a lesser extent the social sciences, is research funding for the student directly, or indirectly through their advisors from research grants and contracts. The US government research and development grants (R\&D) are an important source of this funding. The greater are the R\&D funding levels, lagged by 5 years and adjusted for inflation, the greater would be the expected awarding of $\mathrm{PhD}$ degrees, especially in the sciences. The five year lag is intended to discount for the time between starting and completing a PhD. The funding data are available back to the early 1950s.

An important factor influencing the decision for young males to continue their schooling beyond the Bachelor's level in the post-war period was whether this would effect the likelihood of their being drafted into the US Armed Forces. This, of course, is influenced by the number of draftees and deferment policy. Also, the effect of the draft, or the "cost" of being drafted, would depend on whether this would occur in peacetime or during a war. Three variables to capture these effects are included in the analysis: the number of conscripts inducted into the US Armed Forces (in thousands) five years prior to $\mathrm{PhD}$ completion and dichotomous variables for the Korean War (1950-1953) and the Vietnam War (1964-1975), both lagged five years. Again, five year lags are intended to account for the time between starting and completing a $\mathrm{PhD}$ degree.

Other demand variables are assumed to vary over time, as are the supply of PhD slots. Therefore time trend variables (time and time squared) are also included in the estimating equations.

V. $\quad$ Regression Analysis 
A multiple regression analysis can be used to study in a more systematic manner the trends over time in the number of $\mathrm{DJN} \mathrm{PhD}$ degrees awarded and in the ratio of $\mathrm{DJN}$ to all $\mathrm{PhD}$ degrees. The dependent variables in this analysis are the number of DJN and ratio of DJN to all PhD degrees awarded each year from 1950 to 2004. The explanatory variables include a time trend (TIME) and its square (TIME SQ). During various years in the period under study military conscription and the Korea and Vietnam Wars may have influenced the decision of young men to continue their schooling through to the $\mathrm{PhD}$ to avoid the draft. The draft/war variables are included in the analysis, but they are lagged 5 years under the assumption that doctoral education started because of the draft/wars would take 5 years to result in a completed $\mathrm{PhD}$. R\&D research and development funding, deflated by the consumer price index and expressed in millions of dollars, is also included in the analysis lagged 5 years. Dichotomous variables are added to the equation for three disciplines, the Physical Sciences, Education, and the Humanities, with the Social Sciences as the benchmark. The analyses are computed overall without regard to gender and separately for those identified as having male and female first names. The variables are explained in greater detail in the Statistical Appendix.

Table 1 reports the regression equation for the number of DJN PhDs awarded from 1950 to 2004 for the data for all four disciplines, that is, 4 observations per year for 55 years for a total of 220 observations. ${ }^{10}$ Column (i) is for all DJNs, while columns (ii) and (iii) are for males and females, respectively. The analysis indicates that there was no effect on DJN PhD production of the Korean War (perhaps because it was both unanticipated and relatively short) or conscription into the US Armed Forces, once the Vietnam War variable is held constant statistically. The

10 The Durbin-Watson statistic in Tables 1 and 2 indicates that there is no statistically significant autocorrelation in the residuals in the level and ratio equations. 
Vietnam War had a highly statistically significant effect on all and male, but not female DJN PhDs. R\&D funding has a highly statistically significant effect on male DJN PhD production, but although the coefficient is positive it is much smaller and not quite at the margin of being statistically significant for females.

The discipline coefficients indicate that both male and female DJNs received more PhDs in the physical sciences than in the social sciences (the benchmark), and fewer PhDs in the humanities. Compared to the social sciences, however, fewer PhDs are received by male DJNs in Education, and although more are received by women, the difference between the number of female DJN PhDs in education and the social sciences is not statistically significant.

When only a linear time trend (TIME) is considered it shows a statistically significant decline in male DJN PhDs awarded over the course of the 55 years, but among females there is a significant increase over time. A quadratic time trend is also used (TIME, TIME SQ). ${ }^{11}$ The male DJN PhD production increased in the early years and then declined, other variables the same. The peak for men occurs at time equal to about 18 years or 1967 (recall 1950 is time period 1). Among women, however, the linear term is positive and significant, while the squared term is negative but not statistically significant. The coefficients imply that female DJN production increased throughout the period under study, although with weak evidence for a decline over time in the annual increase.

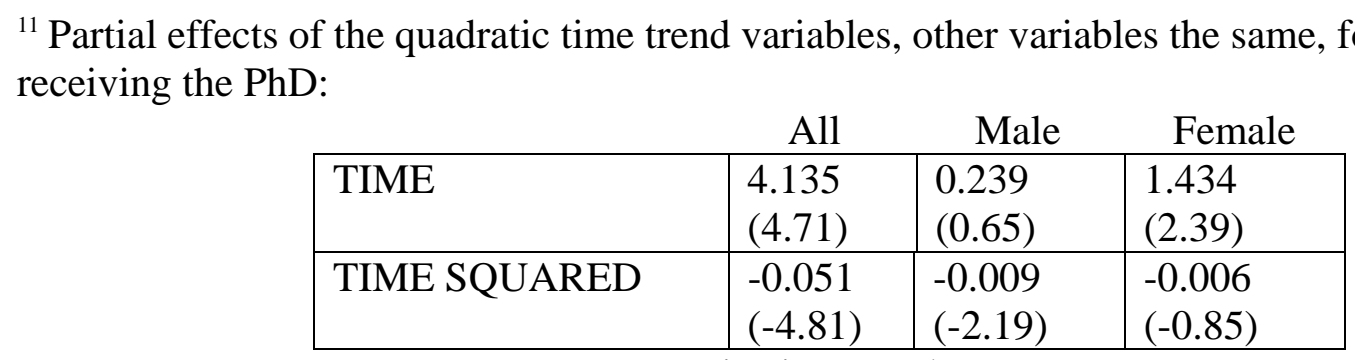

$\mathrm{t}$ - ratios in parentheses 
Table 2 reports the regression equations for the ratio of DJN to all $\mathrm{PhDs}$ awarded as the dependent variable, overall and separately by gender. Overall, the induction variable has a significant negative coefficient, while the two war variables had significant positive coefficients. The interpretation is that the DJNs responded by entering PhD programs more so than others in the two war periods, but outside of wartime the DJNs were less likely than others to seek the $\mathrm{PhD}$ in response to the draft. Male DJNs were more responsive to $\mathrm{R} \& \mathrm{D}$ funding than were others.

Compared to others, DJN men who received a PhD were more likely to get their PhDs in the social sciences than in other disciplines. For women, relatively more of the DJNs were in the sciences (social or physical) than in the humanities or education.

The statistically significant linear time trend indicates that across the entire period there was a decline in the proportion of PhDs received by male and by female DJNs. When the quadratic time variables are considered, the squared term is statistically significant with a negative sign for both genders pooled, but the time coefficients are not statistically significant when the equations are computed separately by gender. ${ }^{12}$ The quadratic specification is also consistent with a general decline over the post-war period in the ratio of DJN to all PhDs produced.

VI. Summary and Conclusions

${ }^{12}$ Partial effect of the quadratic time trend variables, other variables being the same, for the ratio of DJN to all PhDs:

\begin{tabular}{|l|l|l|l|}
\multicolumn{2}{c}{ All } & \multicolumn{1}{c}{ Male } & \multicolumn{1}{c|}{ Female } \\
\hline TIME & 0.000067 & -0.0000084 & -0.00093 \\
& $(0.63)$ & $(-0.07)$ & $(-1.52)$ \\
\hline TIME SQUARED & -0.0000035 & -0.0000021 & 0.0000036 \\
& $(-2.72)$ & $(-1.47)$ & $(0.48)$ \\
\hline
\end{tabular}

t- ratios in parentheses 
This lecture is motivated by the apparent decline in American Jews working as College and University teachers in recent decades, while at the same time the number and proportion of Jews in other professional occupations has increased. It is hypothesized that discrimination against Jews in salaried professional occupations in the pre-WWII period discouraged their entry, but post-WWII this discrimination decreased, and that the decline occurred earliest in College and University teaching jobs (encouraging Jewish entry), and later in other sectors. As employment in other sectors for Jews with advanced degrees become available, the relative attractiveness of College and University teaching declined.

Since the PhD has become the "union card" for College and University teaching, although not all PhDs enter this occupation, the focus in this lecture is on the receipt of the $\mathrm{PhD}$ as an index of entry into the occupation. The data on $\mathrm{PhD}$ awards by year and major discipline, as recorded in University Microfilms, University of Michigan, are studied. Jews are identified through the Distinctive Jewish Name (DJN) technique (36 names), which undoubtedly provides an undercount of Jewish PhDs.

The descriptive statistics reported in the graphs suggest an increase in the number of PhDs received by Jews from 1950 up to the early 1970s, a plateau in the 1970s, with a decline thereafter. The simple data on the ratio show an increase from 1950 to the middle 1950's, after which the proportion of PhDs received by Jews declined. This general pattern appears, as well, among the four major disciplines, Social Sciences, Physical Sciences, Humanities and Education. Multiple regression analysis is used to analyze these trends. More so than for non-Jews, male Jewish PhDs increased in response to war (more so for the Vietnam War than the Korean War), but was less responsive to variations in peacetime conscription into the Armed Forces. Women PhD production showed very little, if any, responsiveness to the war and conscription 
variables. Jewish men appear to have responded more sharply to increases in NSF funding than did others.

Other variables the same, the overall pattern appears to be an increase in the number of Jewish men receiving the PhD, from the early post-WWII period to about 1967, after which it declined. As a proportion of all male PhDs, the decline started in the 1950s and continued thereafter. Jewish women experienced an increase in the number of PhDs throughout the postwar period. Their share among female PhDs increased until about 1979, after which it too declined.

These time trend patterns are consistent with the hypothesis that the rise and decline of American Jews in the receipt of the PhD and in College and University teaching was in response to changing patterns of discrimination against Jews in salaried professional occupations.

The membership of the Association for the Social Scientific Study of Jewry is not immune to these developments. Note the decline in the number of DJN PhDs in the social sciences from the peak in the late 1970s from about 110 per year to about 70 per year recently, a decline of about one-third. Note also the steady decline in the ratio of DJNs to all PhDs in the social sciences. With a smaller absolute size of the pool to draw upon, a decline in the number of young ASSJ members is to be expected. Yet, the decline in the number of young members seems greater than what can be explained by the trends reported here. Perhaps the greater acceptance of Jews and the study of Jews and Judaism in the mainstream of the social sciences has expanded the opportunities for publication in mainstream journals and presentations at mainstream conferences. If so, it may be that the very success of ASSJ in bringing the study of Jews and Judaism into the mainstream may be responsible for the decline over time in young members. 


\section{References}

Alchian, Armen A., and Reuben A Kessel, (1962), “Competition, Monopoly and the Pursuit of Money,” in National Bureau of Economic Research, Aspects of Labor Economics, Princeton: Princeton University Press, pp. 157-183.

Becker, Gary S. (1957), The Economics of Discrimination, Chicago: University of Chicago Press.

Chanes, Jerome A. (1999) “Anti-Semitism and Jewish Security in Contemporary American: Why Can't Jews Take Yes for an Answer?” in Roberta Rosenberg Farber and Chaim I. Waxman, Eds. Jews in America: A Contemporary Reader, Waltham, MA: Brandeis University Press, pp 124-151.

Chiswick, Barry R. (1999), "The Occupational Attainment and Earnings of American Jewry: 1890 to 1990,” Contemporary Jewry, 20, pp. 68-98.

Chiswick, Barry R. (2007), “The Occupational Attainment of American Jewry: 1990 to 2000,” Contemporary Jewry, 27, pp. 112-136.

Diner, Hasia R. (2004) The Jews of the United States: 1654 to 2000, Berkeley: University of California Press.

Freidenreich, Harriet Pass (2007) “Joining the Faculty Club: Jewish Women Academics in the United States” Nashim: A Journal of Jewish Women’s Studies and Gender Issues, No, 13, Spring, pp. 68-101.

Freidman, Milton (1957) “The Methodology of Positive Economics” in Essays in Positive Economics, Chicago: University of Chicago Press.

Himmelfarb, Harold S., R. Michael Loar and Susan H. Mott (1983) “Sampling by Ethnic Surnames: The Case of American Jews” Public Opinion Quarterly, Vol 47, pp 247-260.

Lipset, Seymour M. (1955) “Jewish Sociologists and the Sociology of Jews” Jewish Social Studies, 17, pp. 177-178.

Lipset, Seymour Martin and Everett Carll Ladd, Jr. (1971) "Jewish Academics in the United States: Their Achievements, Culture and Politics” in Morris Fine and Milton Himmelfarb, eds. American Jewish Year Book, Vol 72, NewYork: American Jewish Committee, pp. 89-128.

Ritterbaud, Paul and Harold S. Wechsler (1994) Jewish Learning in American Universities: The First Century, Bloomington: Indiana University Press. 
Shapiro, Edward S. (1992) A Time for Healing: American Jewry Since World War II, Baltimore: Johns Hopkins University Press (Chap 2 The Decline of Anti-Semitism)

Sheskin, Ira M. (1998), “A Methodology for Examining the Changing Size and Spatial Distribution of a Jewish Population: A Miami Case Study,” Shofar: An Interdisciplinary Journal of Jewish Studies, 17 (1) Fall, pp.97-116. 
Table 1

Regression Analysis of PhDs Awarded to DJNs, 1950-2004, by Gender

\begin{tabular}{|l|c|c|c|}
\hline Variable & All DJN & Male DJN & Female DJN \\
\hline TIME & 0.097 & -0.53193 & 0.944483 \\
& $(0.36)$ & $(-4.92)$ & $(5.41)$ \\
\hline INDUCTION & -0.038 & -0.00832 & -0.00594 \\
& $(-2.88)$ & $(-1.57)$ & $(-0.69)$ \\
\hline VIETNAM WAR & 40.552 & 13.63952 & 3.371917 \\
& $(7.13)$ & $(5.97)$ & $(0.91)$ \\
\hline KOREAN WAR & 7.517 & 4.482007 & 2.088929 \\
& $(0.93)$ & $(1.38)$ & $(0.40)$ \\
\hline FUNDING R \& D & 0.0014 & $1.11 \mathrm{E}-06$ & 0.000292 \\
& $(4.92)$ & $(9.76)$ & $(1.59)$ \\
\hline HUMANITIES & -17.855 & -6.07273 & 7.672727 \\
& $(-3.75)$ & $(-3.17)$ & $(2.48)$ \\
\hline PHYSICAL SCIENCE & 147.963 & 18.34545 & 24.01818 \\
& $(31.04)$ & $(9.57)$ & $(7.76)$ \\
\hline EDUCATION & -6.127 & -8.14546 & 1.309091 \\
& $(-1.29)$ & $(-4.25)$ & $(0.42)$ \\
\hline INTERCEPT & 12.971 & 16.41903 & -15.6059 \\
& $(2.05)$ & $(6.47)$ & $(-3.81)$ \\
\hline SAMPLE SIZE & 220 & 220 & 220 \\
Adj R ${ }^{2}$ & 0.90 & 0.76 & 0.64 \\
\hline DURBIN-WATSON & 1.87 & 1.90 & 2.07 \\
STATISTIC & & & \\
\hline
\end{tabular}

NOTE: t-ratios in parentheses

SOURCES: See Statistical Appendix 


\section{Table 2}

Regression Analysis of Ratio of DJNs to All PhDs Awarded 1950-2004, by Gender

\begin{tabular}{|l|c|c|c|}
\hline \multicolumn{1}{|c|}{ Variable } & $\underline{\text { All DJN }}$ & $\underline{\text { Male DJN }}$ & Female DJN \\
\hline TIME & $\begin{array}{c}-0.00021 \\
(-6.67)\end{array}$ & $\begin{array}{c}-0.00017 \\
(-5.08)\end{array}$ & $\begin{array}{c}-0.00065 \\
(-3.64)\end{array}$ \\
\hline INDUCTION & -0.0000073 & $-5.66 E-06$ & $-2.5 \mathrm{E}-05$ \\
$(-4.73)$ & $(-3.41)$ & $(-2.89)$ \\
\hline VIETNAM WAR & 0.0028 & 0.001352 & 0.000389 \\
& $(4.34)$ & $(1.89)$ & $(0.1)$ \\
\hline KOREAN WAR & 0.0021 & 0.002447 & 0.007886 \\
& $(2.25)$ & $(2.4)$ & $(1.47)$ \\
\hline FUNDING R\& D & -0.000000012 & $6.04 \mathrm{E}-11$ & $\begin{array}{c}8.60 \mathrm{E}-08 \\
(1.7)\end{array}$ \\
& $(-0.37)$ & $0.46)$ \\
\hline HUMANITIES & -0.0018 & -0.00238 & 0.021624 \\
& $(-3.29)$ & $(-3.97)$ & $(6.84)$ \\
\hline PHYSICAL & -0.00038 & -0.00721 & -0.00025 \\
SCIENCE & $(-0.69)$ & $(-12.02)$ & $(-0.08)$ \\
\hline EDUCATION & -0.0046 & -0.0059 & -0.00564 \\
& $(-8.37)$ & $(-9.84)$ & $(-1.78)$ \\
\hline INTERCEPT & 0.022 & 0.017612 & 0.034826 \\
& $(31.09)$ & $(22.18)$ & $(8.32)$ \\
\hline SAMPLE SIZE & 220 & 220 & 220 \\
Adj R ${ }^{2}$ & 0.63 & 0.54 & 0.37 \\
\hline DURBIN-WATSON & 2.27 & 1.87 & 2.44 \\
STATISTIC & & & \\
\hline
\end{tabular}

NOTE: t-ratios in parentheses

SOURCES: See Statistical Appendix 
Figure 1

Number of PhDs with DJN (All Fields), 1950-2004

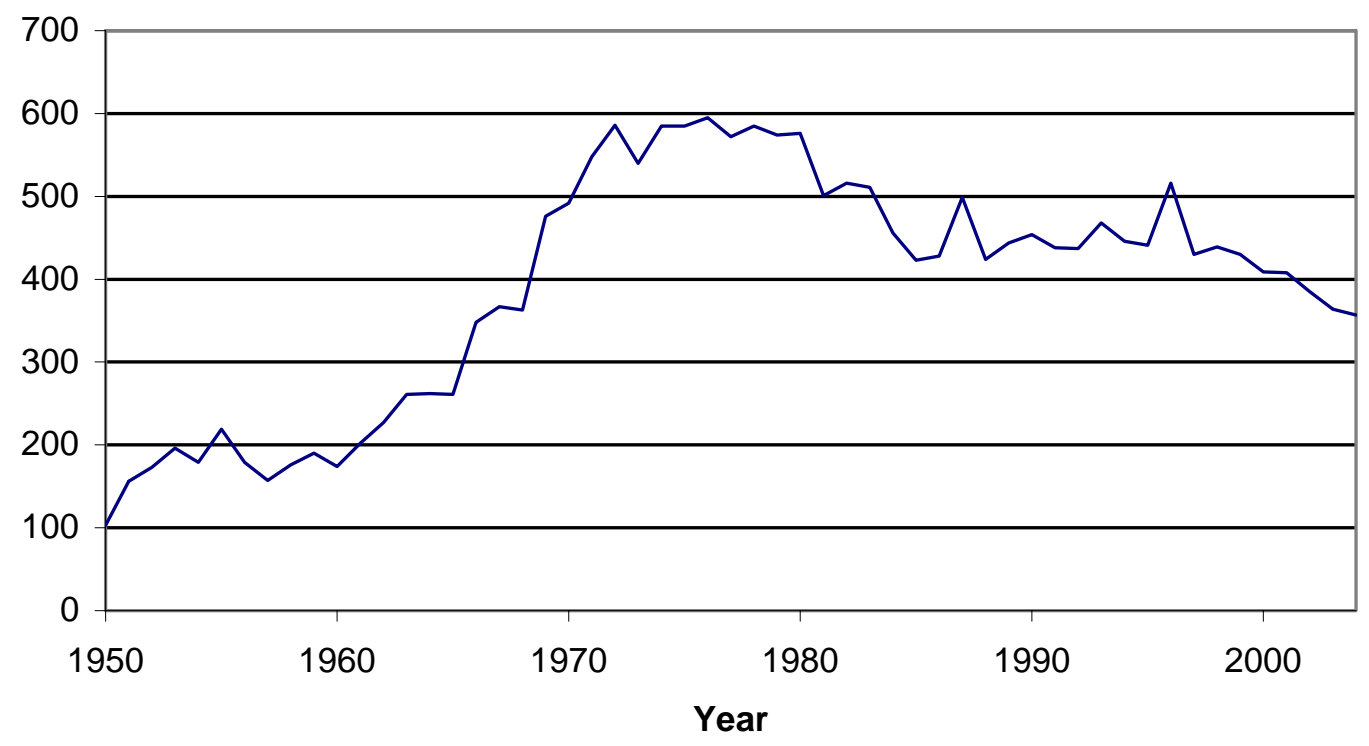

Source: University Microfilms, University of Michigan at Ann Arbor 
Figure 2

Ratio of DJNs to Total Number of PhDs (All Fields), 19502004

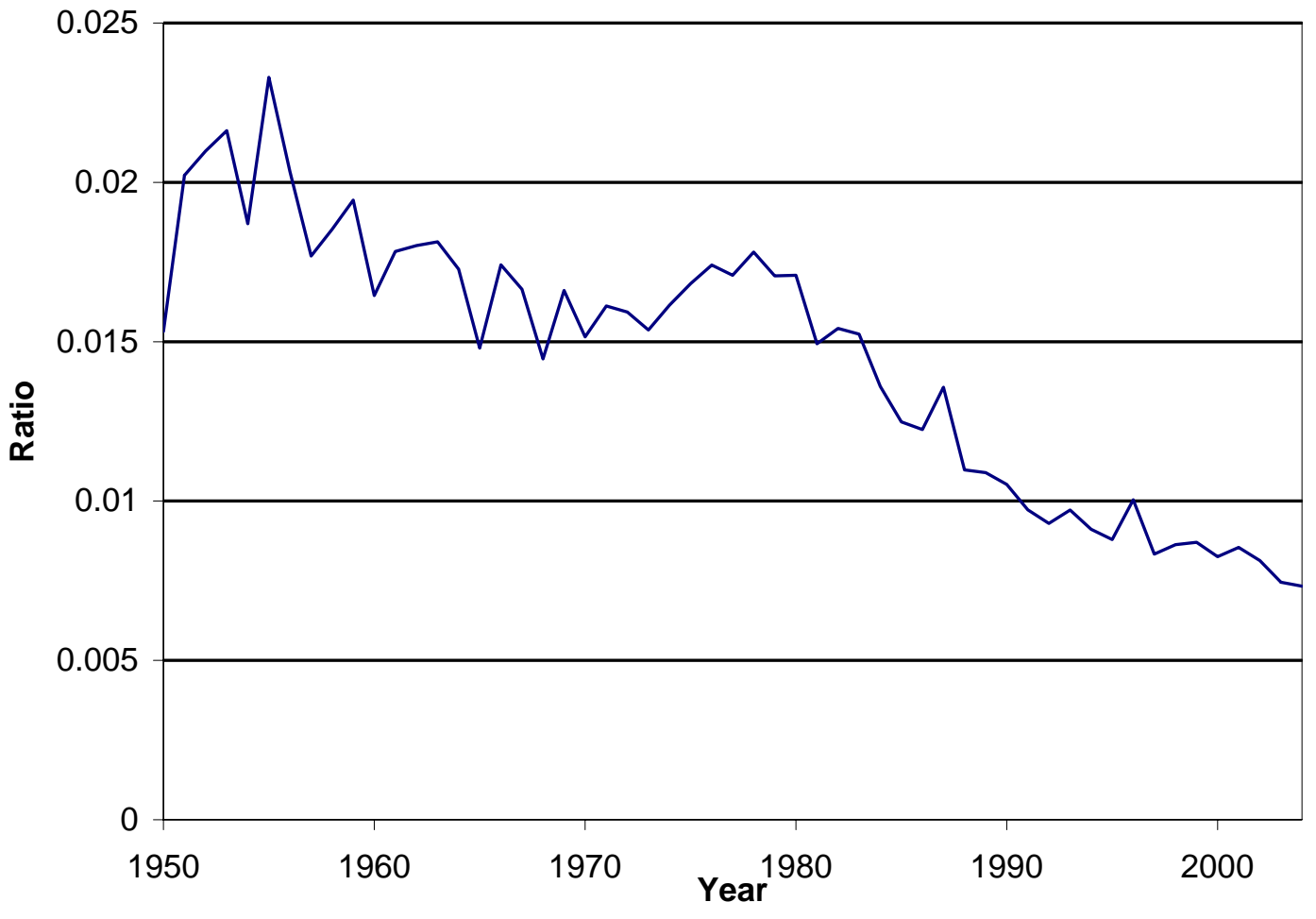

Source: University Microfilms, University of Michigan at Ann Arbor 
Figure 3

Number of PhDs with DJN, by Field, 1950-2004

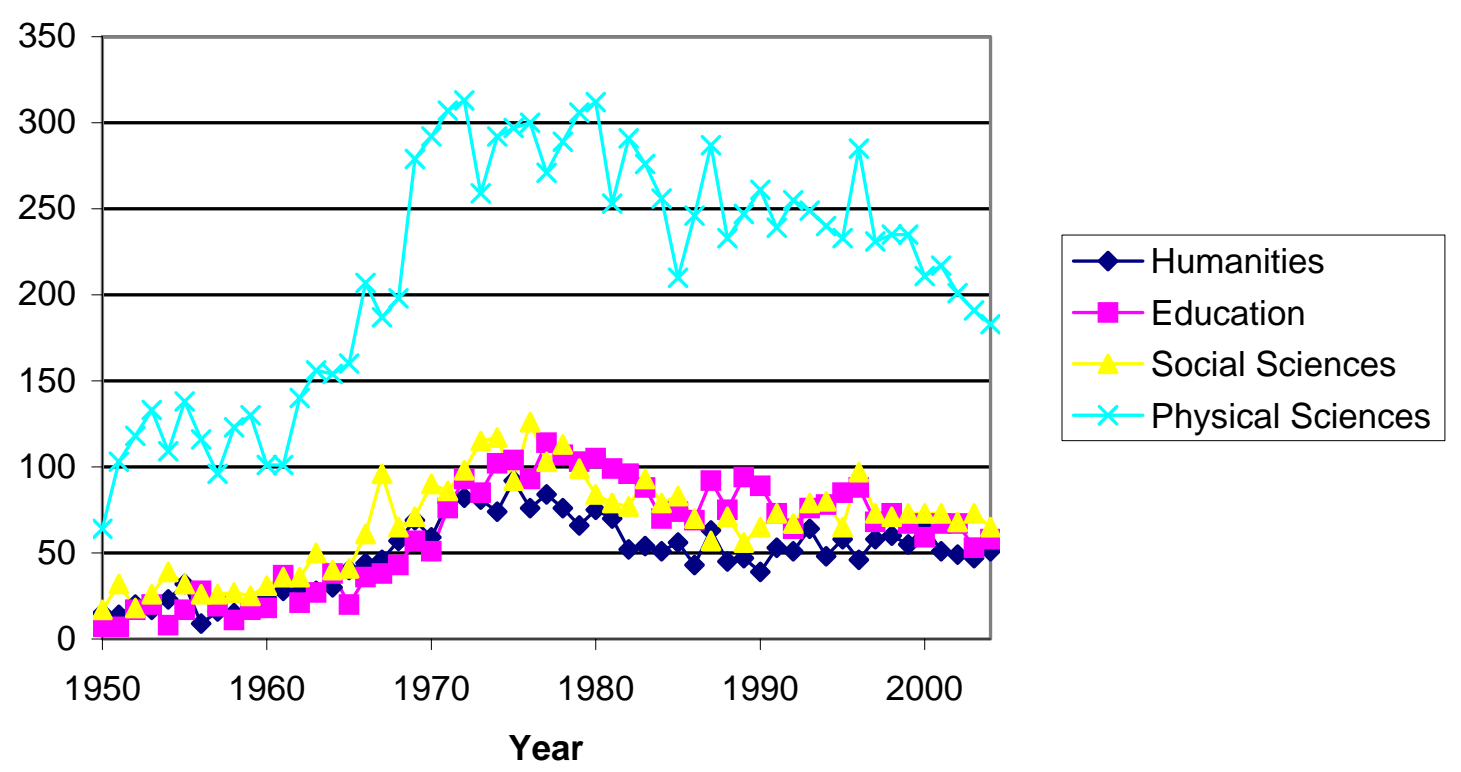

Source: University Microfilms, University of Michigan at Ann Arbor 
Figure 4

Ratio of DJNs to Total Number of PhDs, by Field, 1950-2004

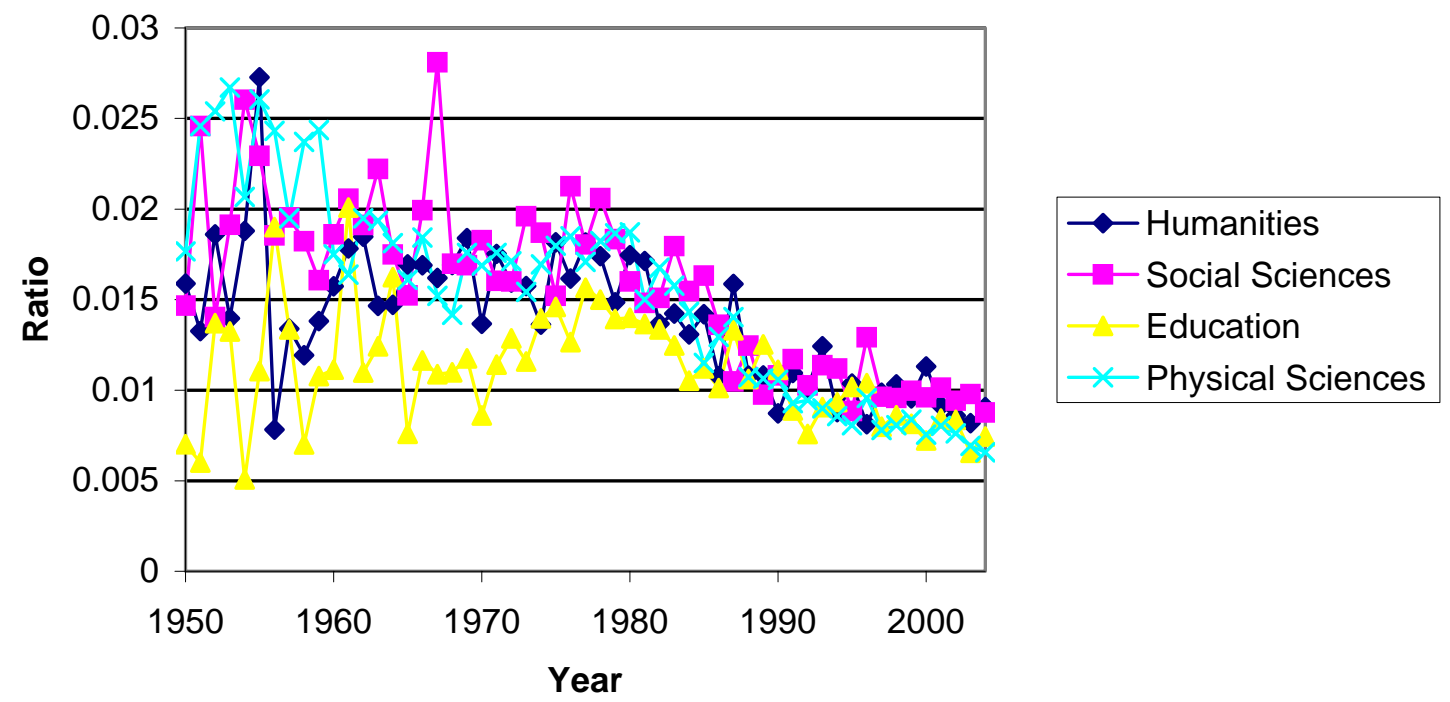

Source: University Microfilms, University of Michigan at Ann Arbor 
Figure 5

Number of PhDs with DJN in all Fields, by Gender, 1950-2004

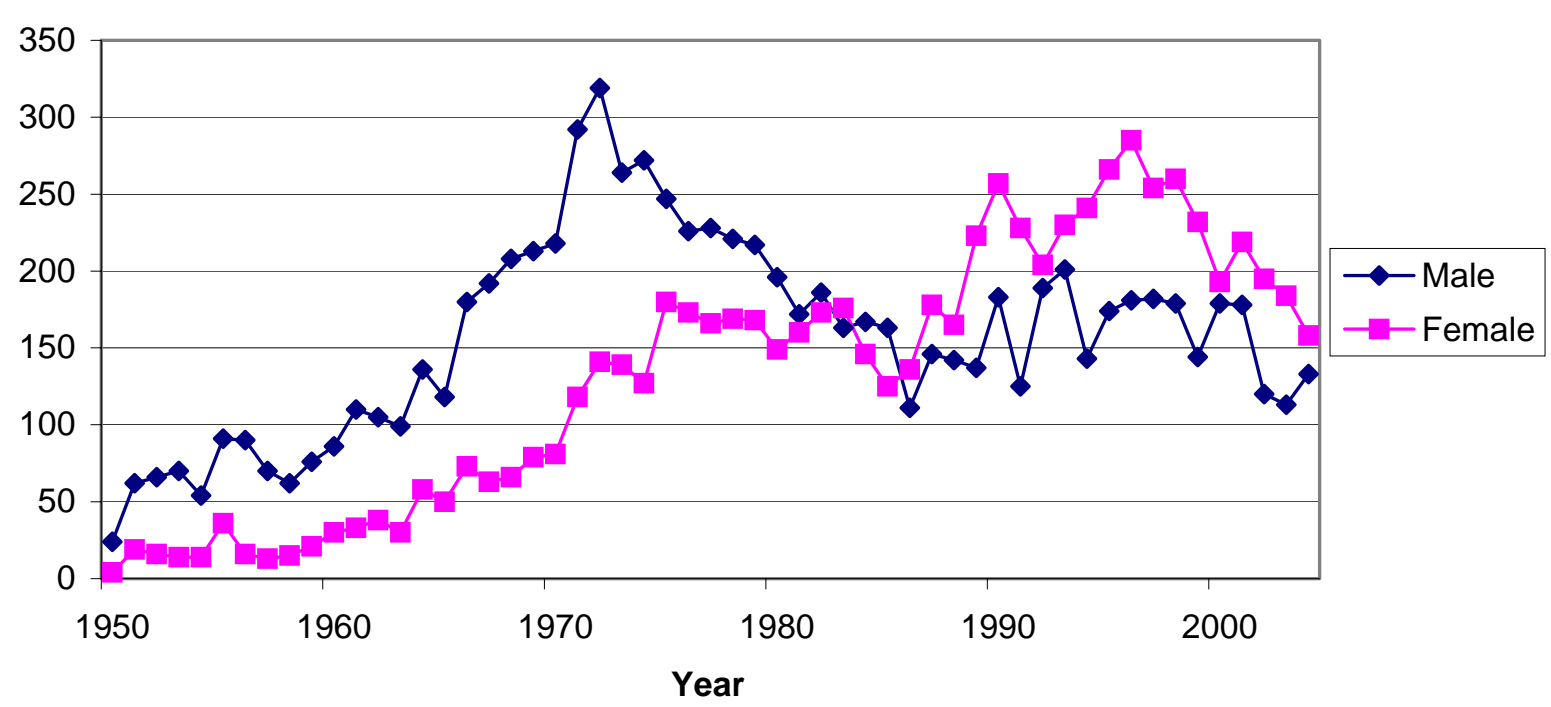

Source: University Microfilms, University of Michigan at Ann Arbor 
Figure 6

Ratio of DJNs to Total Number of PhDs in all Fields, by

Gender, 1950-2004

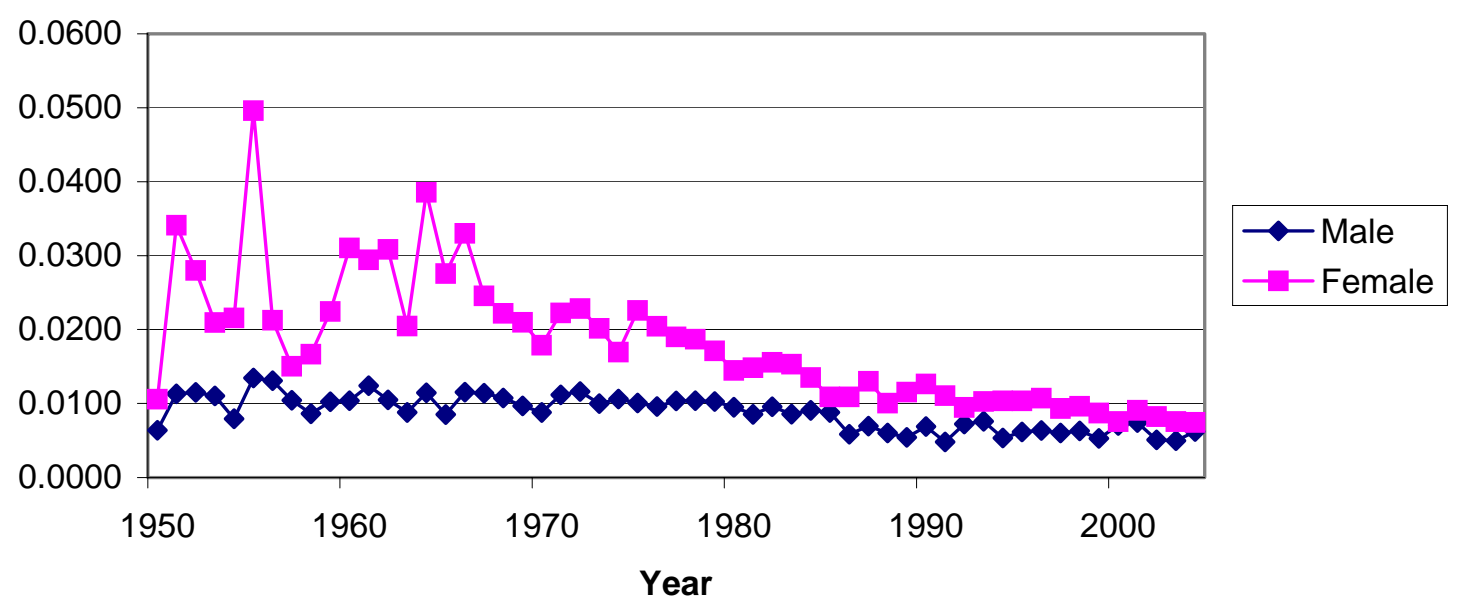

Source: University Microfilms, University of Michigan at Ann Arbor 


\section{Statistical Appendix}

Data Source on PhDs: The data on PhDs awarded annually (1950-2004) in the US are from dissertations abstracted in University Microfilms, University of Michigan at Ann Arbor (Web address: http://wwwlib.umi.com/dissertations/). Data are by discipline (education, humanities, social science, physical science, and all).

DJN: Jews are identified as individuals having a surname or a middle name that is on a list of 36 distinctive Jewish names reported in Sheskin (1998). These names are Berman, Caplan, Cohen, Epstein, Feldman, Freedman, Friedman, Goldberg, Goldman, Goldstein Goodman, Greenberg, Gross, Grossman, Jacobs, Jaffe, Kahn, Kaplan, Katz, Kohn, Levin, Levine, Levinson, Levy, Lieberman, Rosen, Rosenberg, Rosenthal, Rubin, Schwartz, Shapiro, Siegel, Silverman, Stern, Weinstein, and Weiss.

Gender: Identified from a list of the 300 most frequently used boys names and the 300 most frequently used girls names for individuals born in the US, 1960-1969, from the Social Security Administration (web address: http://www.ssa.gov/OACT/babynames/). The 300 most frequently used boys names constitute 88 percent of all boys born in the US in this period and for girls it was 78 percent. If a name appears on the list for both genders all persons with that name were assigned the higher ranked gender (e.g., as Leslie had a higher rank among girls, all Leslie's in the PhD data were assumed to be female.) For individuals with names not on either list, gender is coded as unknown.

Ratio: Dependent variable equal to the ratio of DJN to all PhDs awarded by year, separately by discipline and overall.

Induction: The number of people, in thousands, conscripted into the military five years previously. Data taken from the US Selective Service (Web address: http://www.sss.gov/induct.htm).

Vietnam war: A dichotomous variable that equals one if the Vietnam war (1964-1975) was in progress five years previously, and zero it it was not in progress.

Korea war: A dichotomous variable that equals one if the Korean war (1950-1953) was in progress five years previously, and zero it it was not in progress.

Research and Development Funding: All federal funds given five years previously to research and development in millions of dollars. Values are deflated by CPI with a base year of 1982, taken from the Bureau of Labor Statistics (web address ftp://ftp.bls.gov/pub/special.requests/cpi/cpiai.txt). Data before 1951 have been assigned the value for 1951. Data on funds are taken from the NSF Survey of Federal Funds for Research and Development (web address: http://www.nsf.gov/statistics/showsrvy.cfm?srvy_CatID=4\&srvy_Seri=10).

Time: Starting as $1950=1$, increases by one for each successive year. 